\title{
Presence of Ecophysiologically Diverse Populations within Cobetia marina Strains Isolated from Marine Invertebrate, Algae and the Environments
}

\author{
Elena P. IVANOVA ${ }^{1,6 *}$, Richard Christen ${ }^{2}$, TOMOO SAWABE ${ }^{3}$, Yulia V. AleXeEVA ${ }^{1}$, ANATOLY M. LySENKO ${ }^{4}$, \\ VICTOR P. CHELOMIN ${ }^{5}$ and VALERY V. MiKHAILOV ${ }^{6}$ \\ ${ }_{1}^{1}$ Swinburne University of Technology, PO Box 218, Hawthorn, Vic 3122, Australia \\ ${ }^{2}$ UMR6543 CNRS-Université de Nice Sophia Antipolis, Centre de Biochimie, Parc Valrose, F06108 Nice cedex \\ 2, France \\ ${ }^{3}$ Laboratory of Microbiology, Graduate School of Fisheries Sciences, Faculty of Fisheries, Hokkaido University, \\ 3-1-1 Minato-cho, Hakodate 041-8611, Japan \\ ${ }^{4}$ Institute of Microbiology of the Russian Academy of Sciences, 117811 Moscow, Russian Federation \\ ${ }^{5}$ Pacific Oceanological Institute of the Far-Eastern Branch of the Russian Academy of Sciences, Baltiiskaya Str., \\ 43, 690017, Vladivostok, Russian Federation \\ ${ }^{6}$ Pacific Institute of Bioorganic Chemistry of the Far-Eastern Branch of the Russian Academy of Sciences, \\ 690022 Vladivostok, Pr. 100 Let Vladivostoku 159, Russian Federation
}

(Received July 5, 2005-Accepted July 26, 2005)

Over the last decade, taxonomic surveys have recovered sixteen strains of Halomonas-like marine heterotrophic bacteria from different ecological habitats. The sixteen strains were isolated from three N.W. Pacific Ocean habitats: seawater, the mussel Crenomytilus grayanus and the degraded thallus of brown alga Fucus evanescens. These strains were subjected to a taxonomic investigation of their phenotypic/physiological, genetic, and phylogenetic features. Analysis indicates these bacteria belong to Cobetia marina. The study found all strains tolerated $\mathrm{CdCl}_{2}$ concentrations up to $875 \mathrm{mM}$. Taxonomically, the sixteen strains belong to the same species, nevertheless, their physiological features revealed distinguishing characteristics. For instance, strain KMM 296, recovered from the mussel Crenomytilus grayanus, was distinct from other $C$. marina strains by its ability to produce highly active alkaline phosphatase. The majority of $C$. marina strains that were isolated from degraded alga thallus appeared to have a particular metabolic specialisation by utilizing a range of easily assimilable monosaccharides. Notably, despite a high level of genetic similarity ( $80 \%$ of DNA relatedness), the phenotypic features of the strains isolated from degraded alga thallus differed with the type strain $C$. marina LMG $2217^{\mathrm{T}}$. These differences suggest an ecologically adapted population of C. marina at a subspecies level.

Key words: Cobetia marina, ecological population

\section{Introduction}

Our knowledge of microbial community structure and their dynamics at the ecosystem level remains limited because ecosystems and the links between their community members are incredibly complex ${ }^{4,15)}$. During the last decade intensive efforts have made substantial contributions to the

\footnotetext{
* Corresponding author; E-mail: eivanova@swin.edu.au, Tel: +613-9214-5137, Fax: +61-3-9819-0834
}

investigation of the genetic structure of bacteria of diverse ecological communities ${ }^{7,12-13)}$. Innovative molecular techniques have been used to qualitatively describe bacterial communities along with the exploitation of conventional enrichments ${ }^{9,16,17)}$. Yet the paradigm of rapidly enriched/ readily cultivable members of bacterial communities and their ecological functions is not fully understood ${ }^{1,31)}$. Most of marine 'Gammaproteobacteria' represent one of such abundant groups of readily cultivable heterotrophs that are constantly recovered from an array of microbial 
communities $^{7,15,17)}$. Coexistence and survival in diverse environments might be the reason for the evolutionary development of the versatile metabolic pathways observed in 'Gammaproteobacteria'. Such ecosystem-related response is translated in their ability to produce various biologically active compounds of ecological significance ${ }^{26)}$.

Among 'Gammaproteobacteria' Halomonas-like bacteria comprise rather heterogeneous group of halophilic organisms of more than 30 species that were isolated from saline environments ${ }^{5,6,11)}$. Recent phylogenetic analyses confirmed the heterogeneous structure of the genus Halomonas and resulted in the proposal of the new genus, Cobetia to accommodate the single species [Halomonas] marina ${ }^{2,3)}$. Since its first isolation in 1970 by A. B. Cobet, this organism had a turbulent taxonomic history changing generic affiliations from Arthrobacter marinus via Pseudomonas, Deleya, and Halomonas marina ${ }^{3,6,8,11)}$ until recently it was assigned to newly created genus Cobetia ${ }^{2,3)}$. The first strain of this species was originally isolated from littoral water sample at Woods Hole, Massachusetts during the course of the survey of tolerance of some fresh water and marine micro-organisms to nickel ions ${ }^{8)}$. Later on a few more strains were isolated from a Hawaii sea water sample collected near the coast of $\mathrm{Oahu}^{5}$. So far quite limited number of strains have been isolated and subsequently characterized and there are no studies on the occurrence and ecological diversity of these bacteria. We are beginning to appreciate the abundance and diversity of Halomonas-like populations in the open ocean and in coastal waters ${ }^{3)}$. In this context, this study aimed to select tentative Halomonas-like strains isolated from different geographic areas and/or different ecological habitats in order to assess their taxonomic status based on physiological, genetic and phylogenetic analyses. Further, the study aimed to analyze the metabolic pattern of newly identified Cobetia marina strains and the type strain $C$. marina $\mathrm{LMG} 2217^{\mathrm{T}}$ in relation to their ecological habitat. This survey is based on results obtained in this study and review of our previously published work $^{20,24)}$ and is argued that $C$. marina may maintain a habitat-specific identity as perhaps a result of developing specialized microbial populations.

\section{Materials and Methods}

\section{Isolation procedure}

Strains selected for this study are listed in Table 1. The majority of Cobetia marina derived from degraded thallus of a brown alga (Fucus evanescens) recovered over two different settings of enrichment experiments: without (5 strains: KMM 3550, KMM 3377, KMM 8010-8012) and with addition a protein inhibitor for endo-(1,3)-beta-Dglucanases $^{38)}$ (8 strains: KMM 3810-3811, KMM 8013$8018)$. The isolation procedure was described elsewhere ${ }^{22)}$. Pure cultures were maintained on the semi-solid B medium $^{20)}$ in tubes under mineral oil at $4^{\circ} \mathrm{C}$, and stored at $-80^{\circ} \mathrm{C}$ in marine broth 2216 (Difco, USA) supplemented with $20 \%(\mathrm{v} / \mathrm{v})$ of glycerol.

\section{Phenotypic analysis}

The phenotypic and chemotaxonomic properties used for characterization of the isolates were studied as previously described $^{20,21)}$ following standard procedures ${ }^{33)}$. Cell morphology and Gram stain were determined after $24 \mathrm{~h}$ incubation on medium $\mathrm{B}^{20)}$. The motility was determined by examining 18-h cultures in Marine Broth. The physiological and biochemical properties examined were: oxidation/fermentation of glucose; reduction of nitrate and nitrite, oxidase and catalase activity, gelatin liquefaction, arginine dihydrolase, lysine decarboxylase, ornithine decarboxylase, acetoin production (Voges-Proskauer test), accumulation of poly- $\beta$ hydroxybutyrate, sodium requirement $(0,3,6,8,10,12,15$, $20(\mathrm{w} / \mathrm{v}) \mathrm{NaCl}$; indole and $\mathrm{H}_{2} \mathrm{~S}$ production; and the ability to hydrolyze starch, tween-80, casein, and DNA. The growth at different temperatures $\left(4,10,18,37,42,45^{\circ} \mathrm{C}\right)$ was determined in liquid medium $B$. The hemolytic activity of the strains studied was detected on trypticase soy agar with 50

Table 1. List of Cobetia marina strains included in this study

\begin{tabular}{|c|c|c|}
\hline Species & Strain & Geographical origin \\
\hline 1. Cobetia marina & LMG $2217^{\mathrm{T}}$ & Seawater, Woods Hole, Massachusetts, Atlantic ocean, $1 \mathrm{~m}, 1970^{8)}$ \\
\hline 2. Cobetia marina & KMM 296 & $\begin{array}{l}\text { Mussel (Crenomytilus grayanus), the Sea of Japan, Pacific ocean, } \\
5-8 \mathrm{~m}, 1991^{19,32)}\end{array}$ \\
\hline 3. Cobetia marina & KMM 734 & $\begin{array}{l}\text { Seawater, Troitza Bay, Gulf of Peter the Great, the Sea of Japan, } \\
\text { Pacific ocean, } 5 \mathrm{~m}, 1991^{23)}\end{array}$ \\
\hline 4. Cobetia marina & $\begin{array}{l}\text { KMM 3550, KMM 3377, KMM 3810, KMM } \\
\text { 3811, KMM 8010-8018 }\end{array}$ & $\begin{array}{l}\text { Brown alga (Fucus evanescens), the Kraternaya Bay, Kuril Islands, } \\
\text { the Sea of Okhotsk, Pacific ocean, } 3-7 \mathrm{~m}, 1999^{\text {this study, } 22)}\end{array}$ \\
\hline
\end{tabular}


$\mathrm{ml}$ of sheep blood.

\section{Effect of $\mathrm{Cd}^{2+}$ ions on bacterial growth}

The toxicity tests for the isolated strains were performed on plates in the media that were supplemented with $\mathrm{CdCl}_{2}$ $\left(2.5,12.5,25.0\right.$ and $\left.50.0 \mathrm{mg} \mathrm{Cd}^{2+} / \mathrm{L}\right)$ as described elsewhere ${ }^{23)}$. Briefly, the cultures were incubated at $25^{\circ} \mathrm{C}$ for up to 3 days, the growth was monitored visually. For estimation of the accumulation of $\mathrm{Cd}^{2+}$ by selected strains, cells $(0.1 \mathrm{ml})$ adjusted to $A_{550}=0.5 \pm 0.05$ were used to inoculate $100 \mathrm{ml}$ of liquid medium with $200 \mu \mathrm{M} \mathrm{Cd}^{2+}$ and without $\mathrm{Cd}^{2+}$ in $250 \mathrm{ml}$ Erlenmeyer flasks. Cultures were cultivated on a rotary shaker at $160 \mathrm{rpm}$ at $25^{\circ} \mathrm{C}$ for $24 \mathrm{~h}$ and $48 \mathrm{~h}$. The growth was monitored spectrophotometrically at $550 \mathrm{~nm}$. Counts for viable cells were also performed to determine colony forming units (CFU). All experiments were repeated twice to ensure reproducibility.

\section{Genetic analysis}

DNA was extracted from cells grown over night on B medium following the method of Marmur ${ }^{28)}$. The $\mathrm{G}+\mathrm{C}$ content of the DNA was determined by the thermal denaturation method of Marmur and Doty ${ }^{29)}$. DNA-DNA hybridization was performed spectrophotometrically and initial renaturation rates were recorded as described by De Ley et $a l .{ }^{10)}$.

To detect the presence of extra-chromosomal DNA, plasmid DNA was extracted using a Perfectprep Plasmid Mini Kit (Promega, USA) according to the manufacturer protocol. HindIII digested lambda DNA (Promega, USA) was used as a reference of molecular mass standard.

\section{DNA amplification and sequencing}

The 16S rRNA gene was amplified and sequenced by MIDI Labs (Newark, USA). Briefly, primers used for the amplification corresponded to $E$. coli positions 5 and 1540. Amplification products were purified using Microcon 100 (Millipore) molecular weight cut-off membranes and checked for quality and quantity on an agarose gel. Cycle sequencing of the $16 \mathrm{~S}$ rRNA amplification products was carried out using AmpliTaq ES DNA polymerase and Rhodamine dye terminators. The samples were electrophoresed on ABI Prism 377 DNA Sequencer ${ }^{25)}$.

\section{Phylogenetic analysis}

Phylogenetic analyses were done as reported previous$1 y^{24)}$ and explained in detail at: http://bioinfo.unice.fr (section publication, document: Phylogeny_How). Domains used to construct the final phylogenetic trees were positions
741-1401 of strain KMM 296. Phylogenetic trees were constructed according to three methods [BIONJ, maximumlikelihood (ML) and maximum-parsimony (MP)] as described $^{24)}$. 16S rDNA gene sequences of KMM 296, KMM 734, KMM 3377, and KMM 3810, have been deposited in GenBank under accession numbers AY628693AY628696, respectively.

\section{Results and Discussion}

\section{Generic identification}

We selected a total of 15 strains isolated from different ecological communities at different years and from separate ecological habitats on the Russian coast of the Japan Sea and in the Kuril Islands for generic identification. In 1991 sampling was focused on collecting and characterizing isolates from sea water and invertebrates, e.g. mussels Crenomytilus grayanus. From those isolation studies we picked two distinct Halomonas-like strains for further investigations. One of them, KMM 296, produced a highly active intracellular alkaline phosphatase with specific activity of $15000 \mathrm{u} \mathrm{mg}^{-1}$ of protein ${ }^{19,32)}$, while another, KMM 734 , tolerated high $\mathrm{Cd}^{2+}$ concentrations ${ }^{23)}$. Other isolates characterized in this study were representative strains (total of 13) obtained from two different enrichment experiments during degradation of thallus of brown alga (Fucus evenescens $)^{22)}$. The type strain $C$. marina $\mathrm{LMG} 2217^{\mathrm{T}}$ was used as a reference strain.

All together, selected strains shared similar phenotypic characteristics. They were Gram-negative, rod-shaped organisms with 2-5 flagella that formed small $(2-4 \mathrm{~mm})$, round, non-pigmented (off-white) colonies on Marine agar plates. None of the isolates gave evidence for indole, urease, oxidase or showed fermentative growth in the absence of oxygen. All were positive for catalase, proteinase (caseinase) and most of the strains produced DNases (Table 2).

An interesting observation is noted that the surface associated strains, KMM 296 and strains isolated from alga, did not require $\mathrm{Na}+$ for growth and could grow at lower temperature, in contrast to sea water isolates that required $\mathrm{Na}+$ for growth and higher temperature for growth.

We also found a number of phenotypic characteristics that distinguished strains isolated from degraded thallus and the type strain. For example, all strains from alga reduced nitrate to nitrite and utilized a great range of carbon substrates, grew at $4{ }^{\circ} \mathrm{C}$, did not require $\mathrm{NaCl}$ for growth and tolerated up to $15 \% \mathrm{NaCl}$, while the type strain did not reduce nitrate to nitrite, required $\mathrm{NaCl}$ and tolerated to a greater concentration of $\mathrm{NaCl}(20 \%)$ and had different 
Table 2. Comparative phenotypic features of Cobetia marina isolated from different ecological habitats

\begin{tabular}{|c|c|c|c|c|}
\hline Characteristic & LMG $2217^{\mathrm{T}}$ & KMM 296 & KMM 734 & Strains isolated from alga, $n=13$ \\
\hline Habitat & SW & INV & SW & A \\
\hline $\mathrm{Na}+$ required for growth & + & - & + & 0 \\
\hline Nitrate reduction & - & - & - & $100^{*}$ \\
\hline \multicolumn{5}{|l|}{ Production of: } \\
\hline DNase & + & + & + & 76 \\
\hline Lipase & - & - & - & 0 \\
\hline \multicolumn{5}{|l|}{ Growth in $\mathrm{NaCl}$ : } \\
\hline $20 \%$ & + & - & + & 100 \\
\hline \multicolumn{5}{|l|}{ Growth at: } \\
\hline $4^{\circ} \mathrm{C}$ & - & + & - & 100 \\
\hline $42^{\circ} \mathrm{C}$ & + & + & + & 23 \\
\hline Plasmids, $21 \mathrm{kbp}$ : & - & + & - & + \\
\hline \multicolumn{5}{|l|}{ Utilization of: } \\
\hline D-Glucose & + & + & + & 100 \\
\hline Maltose & - & - & - & 100 \\
\hline Lactose & - & - & - & 100 \\
\hline D-Arabinose & - & - & - & 100 \\
\hline D-Galactose & - & - & - & 100 \\
\hline Sucrose & + & - & - & 100 \\
\hline D-Xylose & - & - & - & 100 \\
\hline Glycerol & + & - & + & 100 \\
\hline D-Fructose & + & - & - & 0 \\
\hline D-Mannose & + & - & - & 0 \\
\hline
\end{tabular}

All strains are motile rod-shaped organisms, do not require organic growth factors, oxidase-, arginine dihydrolase, lysine, ornithine decarboxylases, indol, $\mathrm{H}_{2} \mathrm{~S}$, Voges-Proskauer, hemolysis negative and catalase-positive; do not produce amylase, gelatinase, lipase; produce caseinase.

*\% of strains exhibited a positive reaction.

Habitats: SW, seawater; INV, invertebrates; A, algae.

Data were taken in this study and from reference no. 22

range of growth temperatures. Chemotaxonomically, all strains had the characteristic FA composition with three major components 16:0 (11-13\%), 16:1 (n-7) (51-52\%), and $18: 1(\mathrm{n}-7)(26-30 \%)$ which generally accounted for greater than $90 \%$ of the total fatty acids ${ }^{21,22,39}$.

\section{Phylogenetic analysis}

16S rRNA gene sequence analysis of Cobetia marina strains revealed that the organisms were closely related to members of 'Gammaproteobacteria'. Fig. 1 shows a consensus tree between NJ (bootstrap analysis, 1000 replications), ML and MP analysis where complete 16S rDNA gene sequences of KMM 296, KMM 734 were included. The two almost complete sequences of KMM 296 and KMM 734 formed a robust clade with C. marina (Fig. 1). These $16 \mathrm{~S}$ rRNA gene sequences exhibited high level of similarity $99.3 \%$ and $99.8 \%$ respectively for KMM 296 and KMM 734 with the sequence of the type strain C. marina.
Sequence of strain KMM 3550 has been subjected to phylogenetic analysis elsewhere ${ }^{22)}$ and exhibited similar high level of homology $(99.6 \%)$ with the sequences of the strain Cobetia marina.

\section{Genetic analysis}

The $\mathrm{G}+\mathrm{C}$ contents of the DNA were $62-64 \mathrm{~mol} \%$ (as determined by thermal denaturation method). DNA-DNA hybridization data revealed that DNA of sea water isolate KMM 734 and mussel isolate KMM 296 showed $88 \%$ of genetic similarity, and both had lower level of genetic similarity (up to $79-82 \%$ ) with that of algal isolate, KMM 3550. Since strains isolated from degraded alga thallus were all from the same microbial community, they were essentially similar in their pheno- and chemo-taxonomic characteristics and had identical 16S rRNA gene sequences, only one strain, KMM 3550, was taken for DNA-DNA hybridization experiments. DNA-DNA hybridization results also showed 


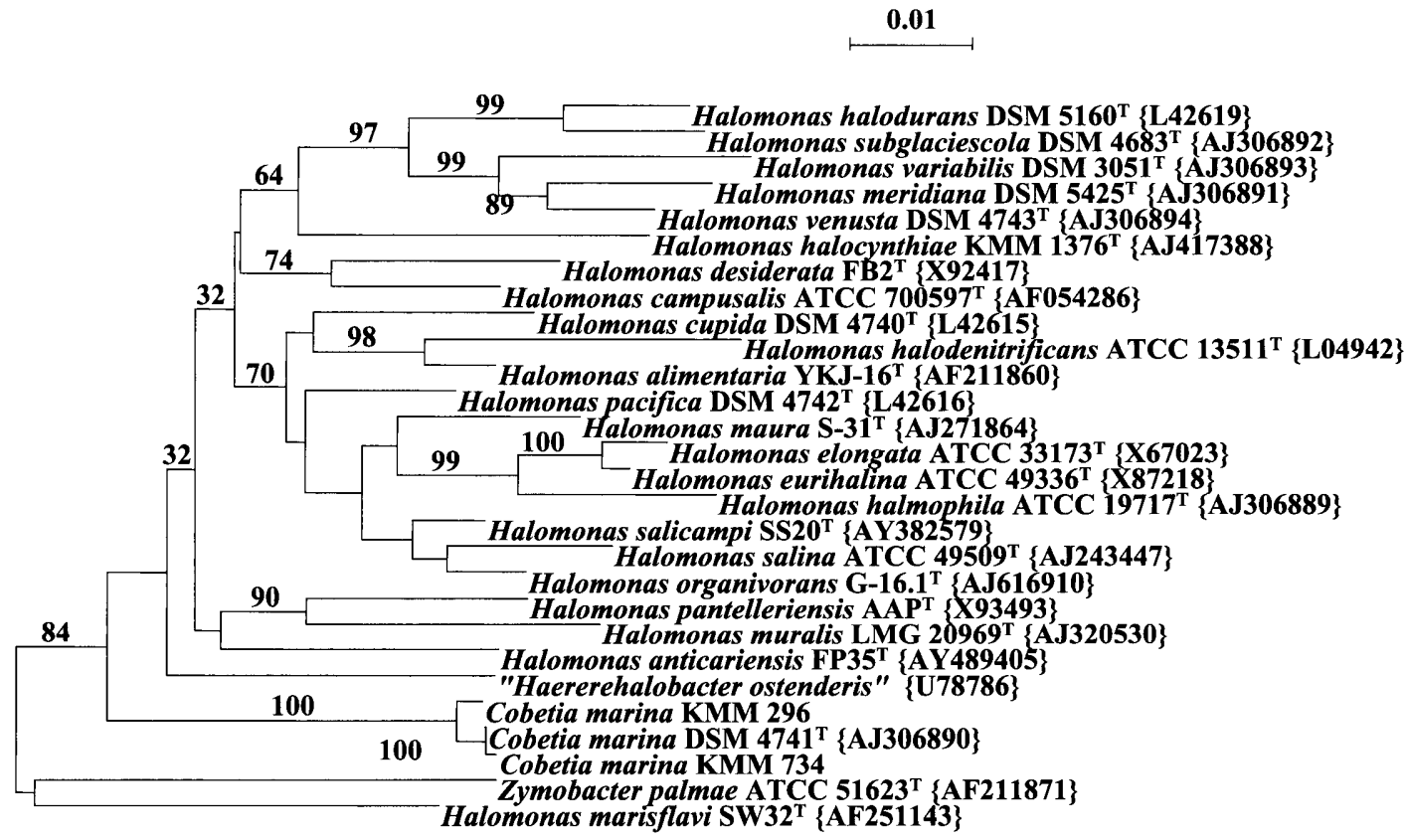

Fig. 1. Phylogenetic position of Cobetia marina within 'Gammaproteobacteria'. The tree represents a consensus tree based on NJ, ML, and MP. The scale bar represents 0.1 nucleotide substitution per position.

Table 3. DNA relatedness among Cobetia marina strains

\begin{tabular}{|c|c|c|c|c|}
\hline Organism & $\mathrm{G}+\mathrm{C}$ content $(\mathrm{mol} \%)$ & C. marina $\mathrm{LMG} 2217^{\mathrm{T}}$ & C. marina KMM 296 & C. marina KMM 734 \\
\hline C. marina $\mathrm{LMG} 2217^{\mathrm{T}}$ & 63.7 & 100 & & \\
\hline C. marina KMM 296 & 62.7 & 80 & & \\
\hline C. marina $\mathrm{KMM} 734$ & 62.8 & 78 & 88 & \\
\hline C. marina KMM 3550 & 62.9 & 79 & 82 & 79 \\
\hline
\end{tabular}

that the levels of genetic similarity of new organisms with the type strain of the genus ranged from 78 to $80 \%$ (Table 3 ). According to generally accepted criterion of the species definition, a threshold value of around $70 \%$ DNA relatedness is recommended for species discrimination ${ }^{37)}$, given that strains that share higher than $70 \%$ DNA relatedness, should also share high phenotypic similarities ${ }^{31,34)}$. There is also a notion that the DNA reassociation similarity of $70 \%$ somewhat underestimates the different mechanisms and the mode and tempo at which microorganism develop ${ }^{34}$. However, so far this value is widely applied as a cut-off value at the level of species ${ }^{30,34)}$. Newly isolated strains had more than $70 \%$ genetic similarity and shared more than $99 \%$ of 16S rRNA gene sequence similarity with the type strain of the species and can be assigned to C. marina. On the other hand, strains studied and in particular those isolated from degraded alga thallus, had no more than $80 \%$ of DNA relatedness and most of the phenotypic features contrasting to those of the type strain as it stated in its species description (Table 1). Therefore, we believe that algal isolates may represent an ecologically adapted population of C. marina on subspecies level.

\section{Cadmium resistance of C. marina}

Since originally the type strain tolerated up to $4 \times 10^{-4} \mathrm{M}$ $\mathrm{NiCl}_{2}{ }^{8)}$, it was of interest to explore whether a capability to tolerate to elevated concentration of heavy metals can be considered as a species-characteristic feature. We carried out additional experiments to test the tolerance to heavy metals (e.g. cadmium) of the rest of the strains belonging to C. marina. One strain, KMM 734 was included in earlier investigation of the effects of cadmium on free living bacteria, associated with marine invertebrates and epiphytes of eelgrass and mechanisms of its detoxification ${ }^{23)}$. Notably, in contrast to other strains (e.g. Pseudoalteromonas spp., Marinobacter sp.) studied in that work, KMM 734 showed 


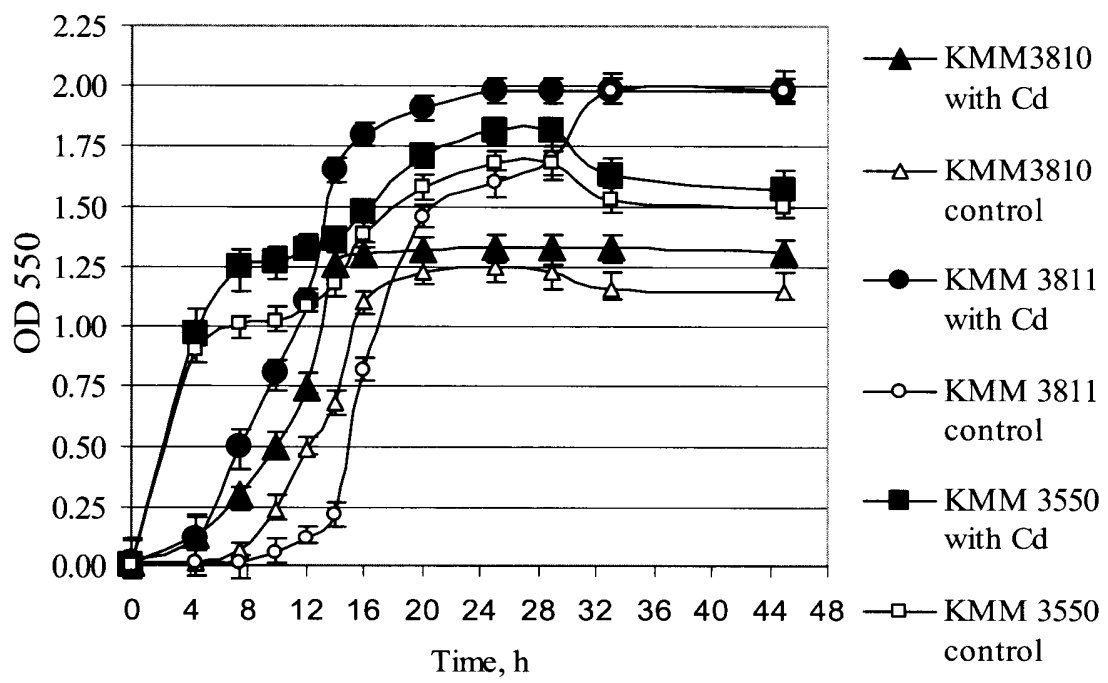

Fig. 2. Effect of cadmium $(200 \mu \mathrm{M})$ on the growth of Cobetia marina strains isolated from degraded alga thallus.

a similar growth pattern in the presence and absence of cadmium $\left(200 \mu \mathrm{M} \mathrm{Cd}^{2+}\right)$. It did not produce any detectable proteins binding cadmium ions or extracellular polysaccharides. Those results suggested that the strain KMM 734 most likely had effective efflux "pumping". Results obtained in this study indicated that all C. marina strains showed similar pattern of growth in the presence and absence of cadmium (200 $\mu \mathrm{M})$ (Fig. 2 illustrates the growth curves of a few selected strains) similar to that reported for

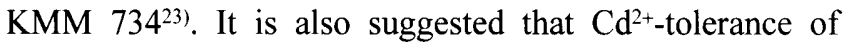
C. marina possibly be mediated by plasmids (and/or by chromosomal DNA), as C. marina strains studied revealed detectable plasmids including some large plasmids of 21 kbp (Table 2). Udo et al. ${ }^{31)}$ and Oger et al. ${ }^{35)}$ reported that plasmid of $21 \mathrm{kbp}, \mathrm{pI} 258$ or pXU5, harbored homologues of cadA gene detected in $\mathrm{Cd}^{2+}$-tolerant bacteria. Further detail investigation on genetic localization and identification of the cadA resistance gene or its homologues in C. marina is underway. Consequently the results suggest that the bacteria of this species are tolerant to heavy metals, in particular to cadmium, regardless their ecological habitats.

\section{C. marina isolated from invertebrates}

One C. marina strain, KMM 296, selected for this study derived from isolates recovered (about 2000 strains) in 1991. They were mainly of Alteromonas-like-phenotype proteobacteria which accounted roughly for $70 \%$ of all the strains ${ }^{18-20,24)}$. Further, these strains have been screened on their production of physiologically active compounds including enzymes ${ }^{18,27,32)}$. It occurred that members of bacterial communities associated with mussels (Crenomytilus grayanus, Patinopecten yessoensis) despite their generic affiliation produced elevated amounts of a particular enzyme, alkaline phosphatase ${ }^{18,19}$. Interestingly, the number of bacterial producers with high levels of enzyme activity increased in late summer, the time of intensive metabolic activity, growth and shell formation of the mussels ${ }^{4}$. These results correlated well with an earlier report of the detection of highly active alkaline phosphatases extracted from mussel tissues during invertebrate metabolic activity ${ }^{18)}$. These and other authors explained this phenomenon by the important role of alkaline phosphatases in the shell formation ${ }^{4,36}$. Accordingly, we believe that the finding of alkaline phosphatase bacterial producers from mussels including C. marina suggests symbiotrophic relationships between microorganisms and invertebrates.

\section{C. marina isolated from alga degraded thallus}

The majority $C$. marina strains included in this study came from two different sets of enrichment experiments. Briefly, in a first series of experiments on the alga thallus degradation, two physiologically and genetically different bacterial groups were recovered (for details, see the reference no. 22). It was shown that two-member microbial community resulted in the unique metabolic cooperation between Pseudoalteromonas issachenkonii and C. marina which has led to enhanced thallus degradation. $P$. issachenkonii most likely played the leading role in the initial stages of algal degradation producing an array of hydrolytic enzymes, while $C$. marina was only able to utilize the products of polysaccharides degradation. In the second series, we modified the experimental set up by adding protein 
inhibitor for endo-(1,3)-beta-D-glucanases ${ }^{38)}$. This modification resulted in dramatic change of the structure of microbial community. Since the conditions for $P$. issachenkonii proliferation were not favorable and its growth was suppressed, other bacterial taxa (e.g. Formosa algae, Brevibacterium spp., Bacillus algicola, etc.) could successfully grow ${ }^{36)}$. Remarkably, among those phylotypes $C$. marina remained detectable and in similar proportions (i.e. reaching up to $40 \%$ of recovered taxa) as in the original enrichment. Although it is difficult to ascertain the representation with which such culture-mediated approach represents the actual functioning of alga degrading microbial community, the replication of recovered C. marina suggests that this phenomenon of the metabolic co-operation for nutrition may reflect the similar mechanisms occurring in nature.

\section{Ecological Significance}

To our knowledge, this is the first study that has specifically investigated the ecological services of $C$. marina isolated from different ecological habitats. The results confirmed that bacteria of this species are tolerant to toxic concentrations of some heavy metals (e.g. Ni and $\mathrm{Cd}$ ) and further suggested that there is obvious metabolic specialisation of $C$. marina depending on ecological environment. A comparison of metabolic profiles of free-living and musselassociated strains revealed that the most prominent producers of alkaline phosphatase were found in $C$. marina isolated from mussels. During alga thallus degradation, the C. marina showed the consistent metabolic response in utilizing products of alga polysaccharides degradation. This observation indicated that $C$. marina could play an important role in alga thallus degradation although such a role remains not fully understood. Our survey also provides insights that $C$. marina may maintain a habitat-specific metabolic activity as perhaps a result of developing specialized microbial populations.

\section{Acknowledgements}

This study was partially supported by funds from Australian Research Council (ARC), by Grants (State Contracts) from Federal Agency for Science and Innovations of the Ministry for Education and Science of the Russian Federation "KMM" and "Scientific Schools;" Grant 05-04-48211 from Russian Foundation for Basic Research; Grants from Presidium of the Russian Academy of Sciences "Molecular and Cell Biology". The authors are thankful to Mr. David Boots for critical reading and editing of the manuscript.

\section{References}

1) Amann, R., B.M. Fuchs and S. Behrens. 2001. The identification of microorganisms by fluorescence in situ hybridisation. Curr. Opin. Biotechnol. 12: 231-236.

2) Arahal, D.R., A.M. Castillo, W. Ludwig, K.H. Schleifer and A. Ventosa. 2003. Proposal of Cobetia marina gen. nov., comb. nov., within the family Halomonadaceae, to include the species Halomonas marina. Syst. Appl. Microbiol. 25: 207-211.

3) Arahal, D.R., W. Ludwig, K.H. Schleifer and A. Ventosa. 2002. Phylogeny of the family Halomonadaceae based on $23 \mathrm{~S}$ and $16 \mathrm{~S}$ rDNA sequence analyses. Int. J Syst. Evol. Microbiol. 52: 241249.

4) Azam, F. and B.C. Cho. 1987. Bacterial utilization of organic matter in the sea. In: Ecology of microbial communities. Cambridge University Press, Cambridge, pp 261-281.

5) Baumann, L., P. Baumann, M. Mandel and R.D. Allen. 1972. Taxonomy of aerobic marine eubacteria J. Bacteriol. 110: 402429.

6) Baumann, L., R.D. Bowditch and P. Baumann. 1983. Description of Deleya gen. nov. created to accommodate the marine species Alcaligenes aestus, A. pacificus, A. cupidus, A. venustus, and Pseudomonas marina. Int. J. Syst. Bacteriol. 33: 793-802.

7) Cho, J.C. and S.J. Giovannoni. 2004. Cultivation and growth characteristics of a diverse group of oligotrophic marine Gammaproteobacteria. Appl. Environ. Microbiol. 70: 432-440.

8) Cobet, A.B., C. Wirsen and G.E. Jones. 1970. The effect of nickel on a marine bacterium, Arthrobacter marinus sp. nov. J. Gen. Microbiol. 62: 159-164.

9) Cottrell, M.T. and D.L. Kirchman. 2000. Natural assemblages of marine proteobacteria and members of the Cytophaga-Flavobacter cluster consuming low- and high-molecular-weight dissolved organic matter. Appl. Environ. Microbiol. 66: 1692-1697.

10) De Ley, J., H. Cattoir and A. Reynaerts. 1970. The quantitative measurement of DNA hybridization from renaturation rates. Eur. J. Biochem. 12: 133-142.

11) Dobson, S.J. and P.D. Franzmann. 1996. Unification of the genera Deleya (Baumann et al., 1983), Halomonas (Vreeland et al., 1080), and Halovibrio (Fendrich 1988) and the species Paracoccus halodenitrificans (Robinson and Gibbons 1952) into a single genus, Halomonas, and placement of the genus Zymobacter in the family Halobacteriaceae. Int. J. Syst. Bacteriol. 46: 550-558.

12) Eilers, H., J. Pernthaler, F.O. Glokner and R. Amann. 2000. Culturability and in situ abundance of pelagic bacteria from the North Sea. Appl. Environ. Microbiol. 66: 3044-3051.

13) Eilers, H., J. Pernthaler and R. Amann. 2000. Succession of pelagic marine bacteria during enrichment: a close look at cultivation-induce shifts. Appl. Environ. Microbiol. 66: 4634-4640.

14) Gonzales de Canales, H.L. and M.P. Martin del Rio. 1985. Rev. Int. Oceanogr. LXXIX-LXXX: 17-21.

15) Gonzalez, J.M., W.B. Whitman, R.E. Hodson and M.A. Moran. 1996. Identifying numerically abundant culturable bacteria from complex communities: an example from a lignin enrichment culture. Appl. Environ. Microbiol. 62: 4433-4440.

16) Gordon, D.M. 2001. Geographical structure and host specificity in bacteria and the implications for tracing the source of coliform contamination. Microbiol. 147: 1079-1085. 
17) Hadstrom, A., J. Pinhassi and U.L. Zweifel. 2000. Biogeographical diversity among marine bacterioplankton. Aquatic Microb. Ecol. 21: 231-244.

18) Ivanova, E.P., G.M. Frolova, N.M. Gorshkova and V.V. Mikhailov. 1992. Directional screening of the bacterial alkaline phosphatase producers. Appl. Biochem. Microbiol. (Moscow) 28: 726-730.

19) Ivanova, E.P., V.V. Mikhailov, E.Y. Plisova, L.A. Balabanova, V.I. Svetashev, M.V. Vysotskii, V.I. Stepanenko and V.A. Rasskasov. 1994. Characterization of the marine bacterium Deleya marina producing a highly active alkaline phosphatase and associated with mussel Crenomytilus grayanus. Biologiya Morya (Russian J. Marine Biol.) 20: 340-345.

20) Ivanova, E.P., E.A. Kiprianova, V.V. Mikhailov, G.F. Levanova, A.G. Garagulya, N.M. Gorshkova, N. Yumoto and S. Yoshikawa. 1996. Characterization and identification of marine Alteromonas nigrifaciens strains and emendation of the description. Int. J. Syst. Bacteriol. 46: 223-228.

21) Ivanova, E.P., N.V. Zhukova, V.I. Svetashev, N.M. Gorshkova, V.V. Kurilenko, G.M. Frolova and V.V. Mikhailov. 2000. Evaluation of phospholipid and fatty acid compositions as chemotaxonomic markers of Alteromonas-like proteobacteria. Curr. Microbiol. 41: 341-345.

22) Ivanova, E.P., I.Y. Bakunina, T. Sawabe, K. Hayashi, Y.V. Alexeeva, N.V. Zhukova, D.V. Nicolau, T.N. Zvaygintseva and V.V. Mikhailov. 2002. Two species of culturable bacteria associated with degradation of brown algae Fucus evanescens Microb. Ecol. 43: 242-249.

23) Ivanova, E.P., V.V. Kurilenko, A.V. Kurilenko, N.M. Gorshkova, F.N. Shubin, D.V. Nicolau and V.P. Chelomin. 2002. Tolerance to cadmium of free living and associated with marine animals and eelgrass marine gamma-proteobacteria. Curr. Microbiol. 44: 357362.

24) Ivanova, E.P., N.M. Gorshkova, T. Sawabe, N.M. Zhukova, K. Hayashi, V.V. Kurilenko, Y.V. Alexeeva, V. Buljan, D.V. Nicolau, V.V. Mikhailov and R. Christen. 2004. Sulfitobacter delicatus sp. nov. and Sulfitobacter dubius sp. nov., respectively, from a starfish (Stellaster equestris) and sea grass (Zostera marina). Int. J. Syst. Evol. Microbiol. 54: 475-480.

25) Ivanova, E.P., Y.V. Alexeeva, S. Flavier, J.P. Wright, N.V. Zhukova, N.M. Gorshkova, V.V. Mikhailov, D.V. Nicolau and R. Christen. 2004. Formosa algae gen. nov., sp. nov., a novel member of the family Flavobacteriaceae Int. J. Syst, Evol, Microbiol. 54: 705-711.

26) Jensen, P.R. and W. Fenical. 1994. Strategies for the discovery of secondary metabolites from marine bacteria: ecological perspec- tives. Annu. Rev. Microbiol. 48: 559-584.

27) Kalinovskaya, N.I., E.P. Ivanova, Y.V.Alexeeva, N.M. Gorshkova, T.A. Kuznetsova, A.S. Dmitrenok and D.V. Nicolau. 2004. Low molecular weight biologically active compounds from marine Pseudoalteromons species. Curr. Microbiol. 48: 441-446.

28) Marmur, J. 1961. A procedure for the isolation of deoxyribonucleic acid from microorganisms. J. Mol. Biol. 3: 208-218.

29) Marmur, J. and P. Doty. 1962. Determination of the base composition of deoxyribonucleic acid from its thermal denaturation temperature. J. Mol. Biol. 5: 109-118.

30) Rossello-Mora, R. and R. Amann. 2001. The species concept for prokaryotes. FEMS Microbiol. Rev. 25: 39-67.

31) Oger, C., T. Berthe, L. Quillet, S. Barray, J.F. Chiffoleau and F. Petit. 2001. Estimation of the abundance of the cadmium resistance gene cadA in microbial communities in polluted estuary water. Res. Microbiol. 152: 671-678.

32) Plisova, E.Y., L.A. Balabanova, E.P. Ivanova, V.B. Kozhemyako, V.V. Mikhailov, E.V. Agafonova and V.A. Rasskazov. 2005. A highly active alkaline phosphatase from the marine bacterium Cobetia. Mar Biotechnol (NY). 7: 173-178.

33) Smibert, R.M. and N.R. Krieg. 1994. Phenotypic characterization, In: Gerhardt F (ed.-in-chief) Methods for General and Molecular Bacteriology. American Society for Microbiology, Washington. D.C., pp 607-654.

34) Stackebrandt, E. 2003. The richness of prokaryotic diversity: there must be a species somewhere. Food Technol. Biotechnol. 41: $17-22$

35) Udo, E.E., L.E. Jacob and B. Mathew. 2000. A cadmium resistance plasmid, pXU5, in Staphylococcus aureus, strain ATCC 25923. FEMS Microbiol. Lett. 189: 79-80.

36) Vinter, V., F. Smid and I. Smorckova. 1987. Factors influencing the activity of cellular alkaline phosphatase during growth and sporulation of Bacillus cereus. Folia Microbiol. 32: 89-95.

37) Wayne, L.G., D.J. Brenner, R.R. Colwell, P.A.D. Grimont, O. Kandler, M.I. Krichevsky, L.H. Moore, W.E.C. Moore, R.G.E. Murray, E. Stackebrandt, M.P. Starr and H.G. Trüper. 1987. Report of the Ad Hoc Committee on Reconciliation of Approaches to Bacterial Systematics. Int. J. Syst. Bacteriol. 37: 463-464.

38) Yermakova, S.P., V.V. Sova and T.N. Zvyagintseva. 2002. Brown seaweed protein as an inhibitor of marine mollusk endo(1->3)-beta-D-glucanases. Carbohydr. Res. 337: 229-237.

39) Yumoto, I., K. Hirota, H. Iwata, M. Akutsu, K. Kusumoto, N. Morita, Y. Ezura, H. Okuyama and H. Matsuyama. 2004. Temperature and nutrient availability control growth rate and fatty acid composition of facultatively psychrophilic Cobetia marina strain L-2. Arch. Microbiol. 181: 345-351. 